\title{
The Examination of Appearance of Income Inequality in Scientific Databases with Content Analysis
}

\author{
Zita Barbara Nagy \\ PhD, Deputy Director, KÖVET Association for Sustainable Economies, Hungary
}

\section{Lívia Benita Kiss}

PhD Student, Pannon University, PhD School of Management Sciences and Business Administration, Hungary

\begin{abstract}
Our modern world society applies widely - but not nearly in generally - the principle that all human beings are equal, or at least should be equal. There used to be and still are societies heavily burdened by inequalities, while others realized various different approaches to equality during the course of history. Almost all societies have become stratified by today. Goal of our study is to examine in online scientific full-text databases Science Direct and Web of Science - when and how key phrases and keywords like income distribution, equality, income inequality, poverty and deprivation appear in literature, as well as the understanding of the emphasis on migration and their changes through the course of scientific history. Furthermore, we attempt to compare the results of the examination carried out in both databases. Scientific papers provide an overview in various sections about the problems of societal stratification, and the equality-inequality, balance-imbalance questions take almost daily roles in various studies. Extreme poverty is an often-used expression today. Our hypothesis seems to be valid in light of the emergence of income inequality as a major topic next to income distribution - as the governmental action for social equalization. As it has been referred to, studies concerning income inequalities have brought along with them various forms of measuring income differences. Despite its advantages, the Gini-index, developed by Corrado Gini deserves special attention, since it has been popularly used to quantify income differences and has become prevalent in the past 15 years. Most recently, the Hungarian-developed Éltetö-Frigyes index has also earned recognition in scientific circles. Our article summarizes the most important findings from our perspective while introducing the major changes in scientific research since the 1970s. We believe that the studies allow for greater advances in solving global problems for a new and fairer global economic order, as they focus on this important topic in ever more investigations.
\end{abstract}

Keywords: income distribution, income inequality, poverty, content analysis.

JEL Classification: C88, I31, O15.

Cite as: Nagy, Z. B., Kiss, L. B. (2018). The Examination of Appearance of Income Inequality in Scientific Databases with Content Analysis. Business Ethics and Leadership, 2(4), 35-45. http://doi.org/10.21272/bel.2(4).35-45.2018.

(C) The Authors, 2018. This article is published with open access at Sumy State University.

\section{Introduction}

Our modern world society applies widely - but not nearly in generally - the principle that all human beings are equal, or at least should be equal. Such an approach often causes misunderstandings and contradictions, since equality is often mixed with complete legality, and a certain degree of variety with inequality. In the social sciences, human equality does not refer to bodily or mental capabilities, but to social rights. Such rights that allow people to reach different opportunities, like acceptable standards of living and welfare (like housing standards or not limited consumption opportunities), and allow them to be partners of their companions in other countries.

There used to be and still are societies heavily burdened by inequalities, while others realized various different approaches to equality during the course of history. Sometimes the same society has exhibited both situations. Almost all societies have become stratified by today. For instance property, employment, income and distribution patterns, control over various influential tools all form different strata in a given society. Not only are these strata econo-societal groups, but they are also more or less insulated from other populations. All these factors contribute to the more and more significant signs of differentiation. Majority of mankind, starting with the slums of large cities, is separated not only from the optimal opportunities required for physical and mental development but even from the minimal opportunities as well. Scientists have noticed this problem of societal 
stratification, and the number of studies investigating the root cause of the problem and a solution for it has significantly been increasing in the past decades. One of the freshest works in the topic that has swept across the world and was in a period the most sought-after book is Capital in the 21st Century by Piketty. The book deals with the extreme concentration of wealth, capital and income. According to the author, income inequalities stem partly from the inequality in salaries, as well as from the fact that the distribution of capital income is even less equal (Piketty, 2015).

Some carefully ponder why inequality is not desired, or what degree of it is tolerable. Supporters of classic economics considered it one of the most important questions of economy, how income was distributed between the participants of the contemporary economy (Kovács, 2010). Ideas of redistribution are based on the point of view that sees too large differences in the income distribution undesirable. Income distribution is fundamentally based on supply and demand, and personal wealth is the result of a series of decisions that mutually influence each other (Heyne, 1991). These decisions are ultimately made by individuals, considering their expectations of profit and monetary input. The easiest and most direct way of reducing wealth inequalities is the taxation of large-income individuals and coincidentally the transfers to those with lower income levels. Distribution between employment income and capital income has always been the focus of distribution questions, exemplified perfectly by the phenomenon that in conventional societies, social inequality has been the cause for revolutions (Piketty, 2015). Increasing inequality not only upsets the social balance between countries and within countries, but it also upsets communities from within (Tóth, 2016). Governments of the time naturally have tools in their hands to alter these situations, redistribution effects of state expenditures dampen the increase of poverty. However, if the governmental support targets the poor less and does not attempt to balance out the inequality, its increase will then be significantly accelerated.

Furthermore, the globalization of the world economy can also aid the increase of wealth inequalities (Harangozó, 2015). The only sustainable way of reducing inequality is the suppression of salaries and capital income that support the growth of inequality. The case of the miners in Marikana shows this well, where the miners went on a strike because of the outstandingly high income of the mine director and the difference between his and the miners' own salaries (Piketty, 2015). Meanwhile, there exist value-based companies, like Ben \& Jerry's, where a "five-to-one" salary norm could work, which caps the highest leadership position's maximum income five times as high as that of the employee making the least amount of money (PatakiRadácsi, 2000). Income and wealth inequalities have effects way beyond their economic consequences, they also have social and societal effects as well. Richard G. Wilkinson and Kate Pickett analyzed data from 23 countries and 50 US states and concluded, that countries or states with greater inequalities display worse performance in terms of various healthcare and social indicators (Wilkinson et al., 2006). Social, economic and political polarization factors in the world are displayed significantly, and therefore are amongst the most researched topics in multiple disciplines (Gyuris, 2014).

We believe that economists must answer different challenges than for instance in the time of Keynes. Economists must know more about the real economy, and its fundamental mechanisms. Issues governing current economical problems are different to those of previous eras. Inequality, the unsolved problem of income differences create new challenges for economic scientists. The topic nevertheless deserves more attention, since economic problems have changed direction so that inequality has become the dominant question.

The goal of the study is to investigate, how keywords and key phrases of the literature appear in online fulltext databases, like wealth distribution, equality or income inequality, as well as poverty and deprivation; furthermore the emphasis on migration, and how all these factors have changed throughout the scientific history. During the research, it has been hypothesized that from the 1970s onwards, alongside poverty, deprivation and migration, the increase in income inequality has taken the biggest role.

\section{Material and Methods}

A thorough investigation of the literature resulted in the definition of relevant keywords for the best synopsis of the topic, which are as follows: income distribution, income inequalities, center-periphery, poverty, migration, Gini index, equality, subsistence level, equal, deprivation, dual index.

Word cloud or a picture collated by highlighting words can not only be a design element, but also an important illustration as well. Multiple online tools are available to create a word cloud. Our research used the https://wordart.com/ online word cloud creator tool. 
The two most significant online international full-text databases - Science Direct and Web of Science - were chosen for the frequency analysis of the keywords, so a quantitative content analysis was carried out. According to Ferenc Gyuris, it can be noted that the national works relating to the topic (especially researches of local inequalities) are mostly built upon the approach of the 1950s and 1960s American social scientific thinking`s conceptional and methodical foundations (Gyuris, 2014). Content analysis is a relatively new method in the field of social science. The first methodical book (Content analysis in communication research), that deals with content analysis, was published in 1952 and written by Bernard Berelson, and founded quantitative content analysis, which is considered to be the classic form of the method.

Science Direct is the full-text database of the publisher Elsevier. A combination of the services provides the best and broadest access to multiple types of electronic sources. Available content of Elsevier Science Direct in Hungary: more than 2500 full-text, reviewed journals, 17000 links to multiple journals covering all areas of scientific life, more than 9.5 million full-text articles (www.eisz.hu).

Web of Science is the bibliographical database of ISI (Institute for Scientific Information). More than 12000 renowned and high impact factor journals help access multidisciplinary information. This tool allows users to navigate literature in all directions, and research all areas until 1975 and find all relevant information to their individual research (http://www.eisz.hu).

Data preparation and result evaluation were carried out in Microsoft Office Excel 2016.

\section{Results and Discussions}

Thorough research of literature resulted in the identification of relevant keywords to the topic, which was then illustrated for the readers using a word cloud (Figure 1).
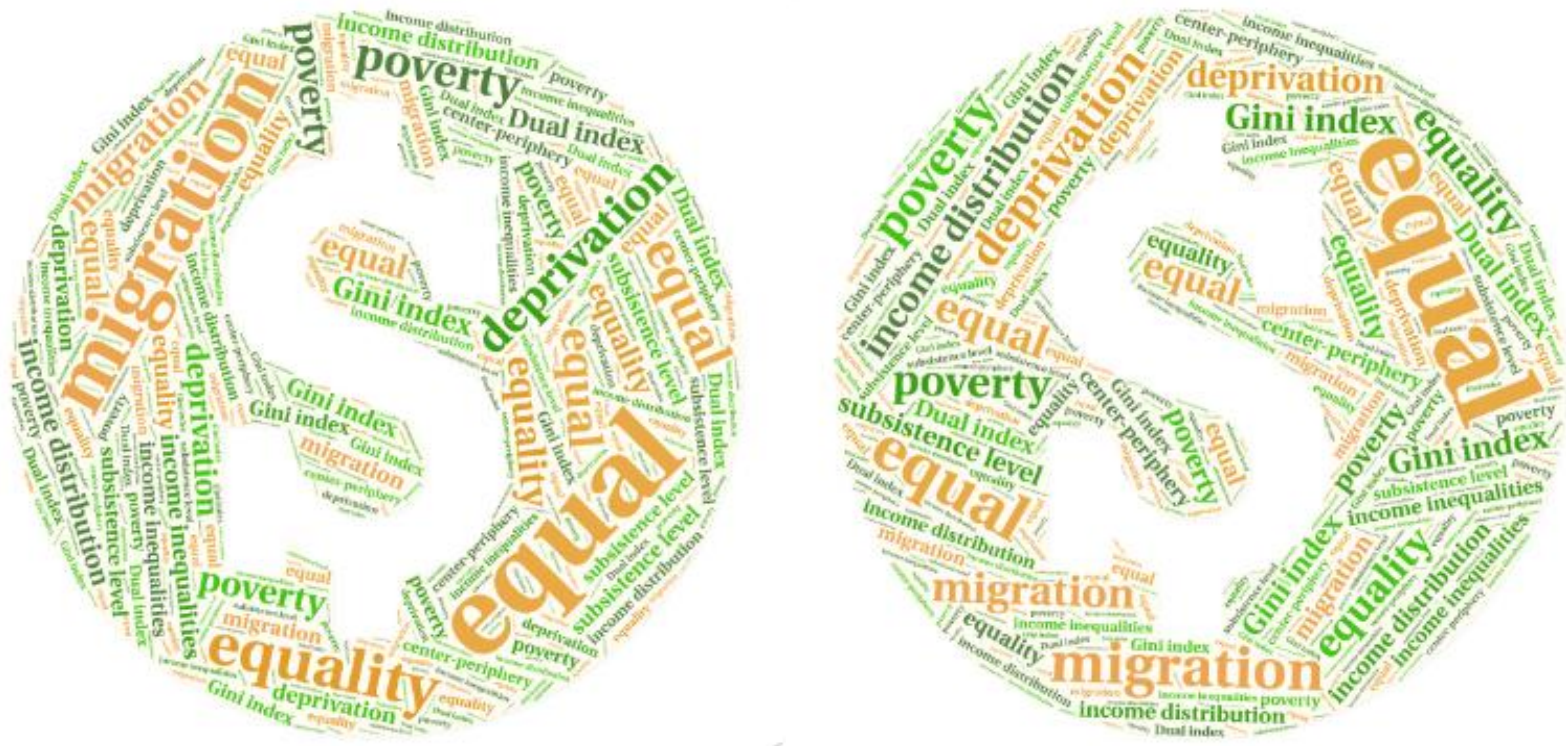

Figure 1. Word cloud using weighted Science Direct and Web of Science number of hits

Source: Own editing using www.wordout.com/create online word cloud creator tool

Our word cloud was formatted to the topic itself. Size of the words reflects their frequency of appearance in the online scientific full-text databases. The number of their appearance was weighted and the determined weights were used to allocate appropriate font size to individual keywords. Three most frequent attributes were highlighted using orange color, to put even more emphasis on them.

\section{First appearance of keywords in Science Direct}

Table 1 summarizes the first appearance of the investigated keywords in the database of Science Direct. In some cases - earliest appearance and indicators - the text had to be examined deeper, including the wording and the use of the keyword itself, to ensure that its use was relevant to the investigated topic.

The earliest appearance of the word "equal" was found in a Latin text from 1652. Its meaning in Latin was the same as today. However, this particular appearance cannot be linked to our topic in question, since monography 
deals with herbs. Therefore, its next usage and the wording was also researched. In 1654, another Latin study (Christiaan Huygens: Illustrium Quorundam Problematum Constructiones. De Circuli Magnitudine Inventa, pp. 45-72) uses the word, which pertains arithmetics and structures, so to some degree, it can be linked to the topic in its mathematical relation.

Based on Table 1, multiple investigated keywords - migration, deprivation and poverty - were first mentioned in the 1820s in medical studies. The context of the researched attributes was also analyzed, and it was concluded that they do refer to our topic. "Deprivation" can be used as an example from 1825, where it was used first in the context of hospital treatments. Indicators and measures related to our topic - Gini index and dual index - first appeared at the beginning of the 1970s. The dual index first appeared in Science Direct in 1967. However, it was used in a geographical study, where it was not used in the same sense as our dual index, but rather in the context of dual indicing in soil studies. According to the analyzed database, the dual index was first used thereafter in a 1970 publication by Donald A. Wood (Organizational Behavior and Human Performance, Volume 5, Issue 6, November 1970, pp. 555-575), who mentioned it in the evaluation of work relative to attitudes. The Gini index was first mentioned in Eytan Sheshinski`s study, following the dual index in 1972.

Table 1. First appearance of keywords in Science Direct`s database

\begin{tabular}{|c|c|c|c|c|c|}
\hline Keyword & $\begin{array}{l}\text { Year of first } \\
\text { appearance }\end{array}$ & Author & Publication & Title & Additional information \\
\hline $\begin{array}{c}\text { income } \\
\text { distribution }\end{array}$ & 1935 & $\begin{array}{l}\text { Special } \\
\text { articles }\end{array}$ & The Lancet & $\begin{array}{c}\text { The present-day } \\
\text { openings of medical } \\
\text { practice }\end{array}$ & $\begin{array}{c}\text { Volume 226, Issue 5844, } \\
31 \text { August } 1935, \\
\text { Pages 512-516 }\end{array}$ \\
\hline income inequality & 1966 & Mark Blaug & $\begin{array}{l}\text { Business } \\
\text { Horizons }\end{array}$ & $\begin{array}{l}\text { Social mobility and } \\
\text { reserves of talent }\end{array}$ & $\begin{array}{c}\text { Economics of } \\
\text { Education, 1966, } \\
\text { Pages 87-97 }\end{array}$ \\
\hline center-periphery & 1939 & - & Tubercle & Current literature & $\begin{array}{c}\text { Volume 20, Issue 9, June } \\
\text { 1939, Pages 438-443 }\end{array}$ \\
\hline poverty & 1823 & - & The Lancet & Surgical lectures & $\begin{array}{c}\text { Volume 1, Issue 1, } 5 \\
\text { October 1823, Pages 3-10 }\end{array}$ \\
\hline subsistence level & 1907 & - & Public Health & Housing & $\begin{array}{c}\text { Volume } 20 \text {, October } \\
\text { 1907-February 1908, } \\
\text { Page } 208\end{array}$ \\
\hline migration & 1825 & - & The Lancet & ST. Thomas's Hospital & $\begin{array}{c}\text { Volume 4, Issue 99, } 20 \\
\text { August } 1825 \text {, Pages } 211 \text { - } \\
216\end{array}$ \\
\hline Gini index & 1972 & $\begin{array}{c}\text { Eytan } \\
\text { Sheshinski }\end{array}$ & $\begin{array}{l}\text { Journal of } \\
\text { Economic } \\
\text { Theory }\end{array}$ & $\begin{array}{l}\text { Relation between a } \\
\text { social welfare function } \\
\text { and the Gini index of } \\
\text { income inequality }\end{array}$ & $\begin{array}{c}\text { Volume 4, Issue } 1 \text {, } \\
\text { February } 1972 \text {, Pages } 98 \text { - } \\
100\end{array}$ \\
\hline equality & 1824 & - & The Lancet & $\begin{array}{l}\text { Amputation at the hip } \\
\text { joint, as performed at } \\
\text { Edinburgh }\end{array}$ & $\begin{array}{l}\text { Volume } 1 \text {, Issue } 22,9 \\
\text { February } 1824, \text { Pages } \\
291-296\end{array}$ \\
\hline equal & 1652 & $\begin{array}{c}\text { Jan Baptist } \\
\text { van Helmont }\end{array}$ & $\begin{array}{l}\text { Ortus Medicinæ } \\
\text { id est Initial } \\
\text { Physicæ } \\
\text { Inaudita }\end{array}$ & $\begin{array}{l}\text { In Verbis, herbis, \& } \\
\text { lapidibus est magna } \\
\text { virtus }\end{array}$ & 1652, Pages 458-466 \\
\hline deprivation & 1825 & - & The Lancet & ST. Thomas's Hospital & $\begin{array}{c}\text { Volume } 4 \text {, Issue } 89,11 \\
\text { June } 1825 \text {, Pages } 315- \\
317\end{array}$ \\
\hline dual index & 1967 & $\begin{array}{l}\text { S. W. Grouse, } \\
\text { Jr. and M. } \\
\text { Swarden }\end{array}$ & $\begin{array}{c}\text { Journal of } \\
\text { Terramechanics }\end{array}$ & Universal drag law & $\begin{array}{c}\text { Volume } 4 \text {, Issue } 3,1967, \\
\text { Page } 70\end{array}$ \\
\hline
\end{tabular}

Source: Own compilation based on Science Direct database 


\section{Frequency of appearance analysis of keywords}

Comparing the keyword search results of the two analyzed databases, the order of magnitude difference in the hits is startling. While Web of Science resulted in slightly over 1 million hits for the searched attributes, in the system of Science Direct they appeared more than 4.5 million times. However, it has to be noted that Web of Science allows for searches dating from 1975, whereas Science Direct has access to works dating back to the 1600s. In the Science Direct search, balance, migration and equality, in Web of Science, balance, migration and deprivation take the imaginary podium finish.

In the following, select examples of the frequency analysis of some important keywords are going to be detailed. Figure 2 shows the data about mentions of income distribution and income inequality, based on Science Direct`s database.

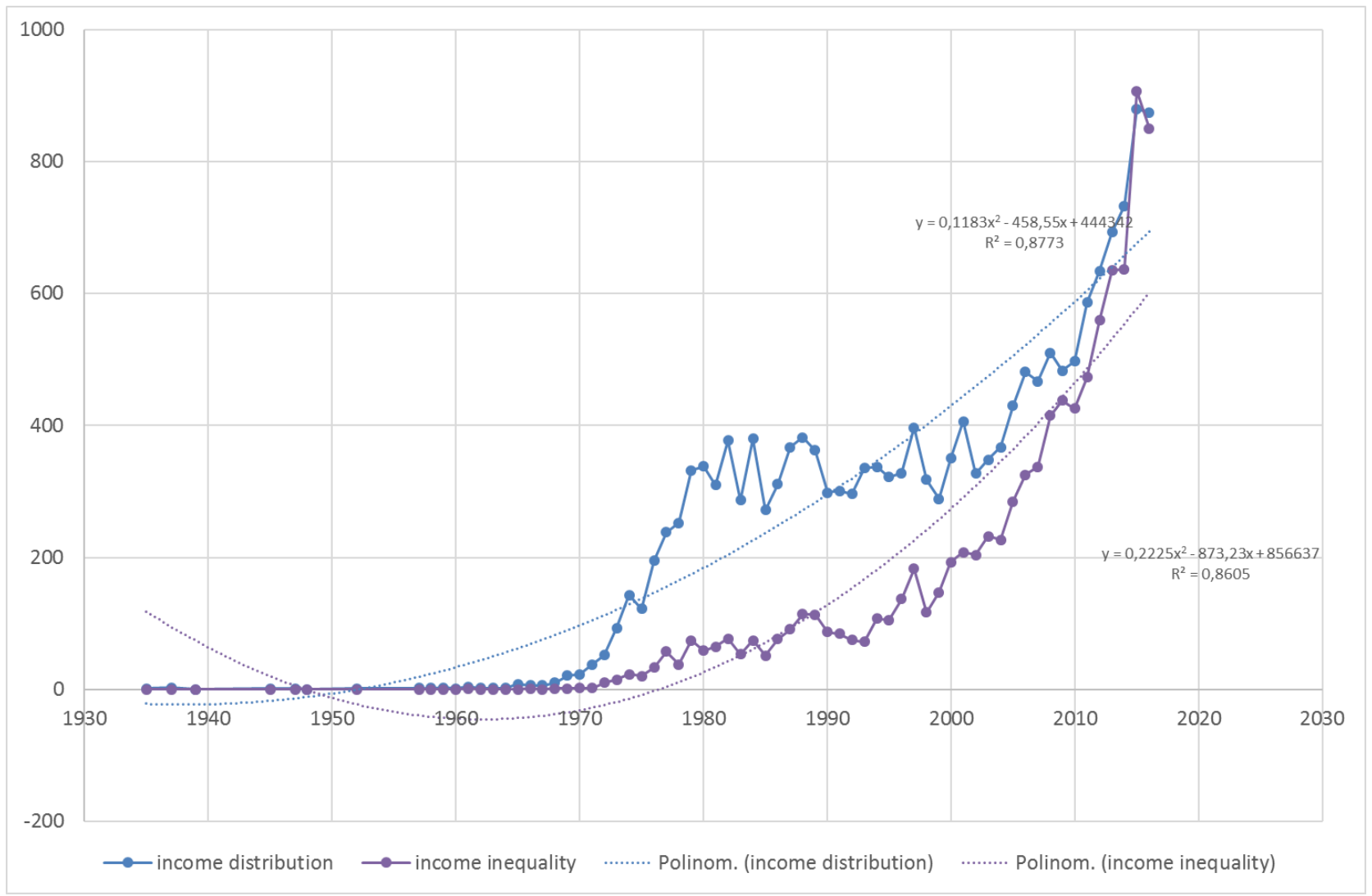

Figure 2. Frequency of appearance of income distribution and income inequality in the Science Direct`s database

Source: Own compilation based on Science Direct's database

It is easy to recognize that the 1970s have brought about an exponential increase in the number of publications on the topic. To analyze the trends in the case of the two data lines, it is worthwhile to apply polynomial trendlines. This trendline is well applicable to fluctuating data, especially the parabola is well known and used most frequently. The two-polynomial trendlines display the correspondence between time and the appearance of keywords. It should be noted that the $\mathrm{R}^{2}$ value means in both cases a good approximation, and the trend of wealth inequality approaches wealth distribution quite closely. Based on these it can be stated that the question of income inequality is almost on the same priority level in scientific publications, as that of wealth distribution.

Figure 3 was based on the database of Web of Science, where mentions of income inequality majorly lack behind mentions of the income distribution. 


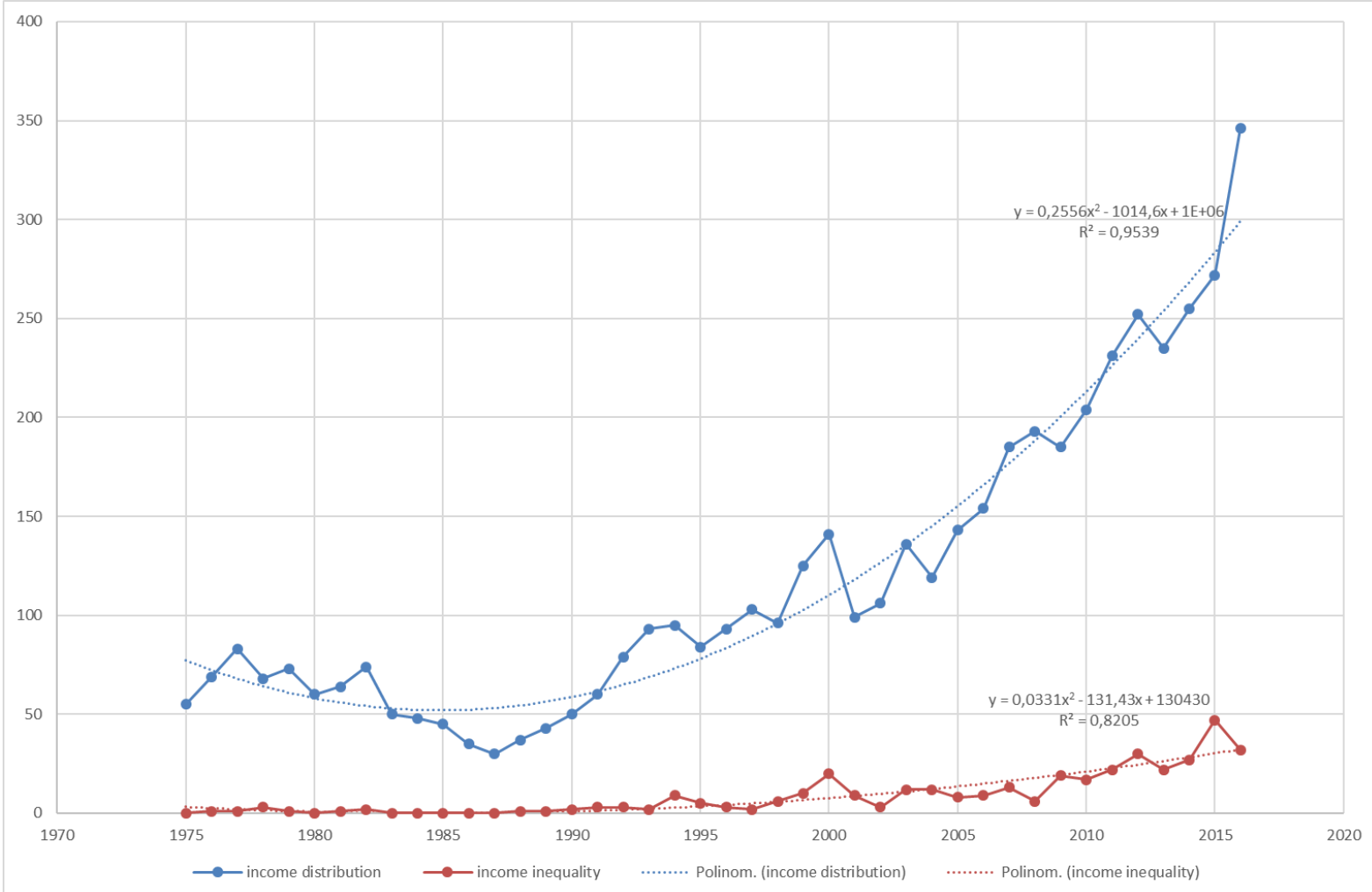

Figure 3. Frequency of appearance of income distribution and income inequality in the Web of Science database Source: Own compilation based on Web of Science`s database

Researches of income inequalities have introduced various forms of measurability for income differences. Socialist countries were unique in their ways of income payments, and even the Western countries were interested in their model.

Figures 4 and 5 show well that two important measurements constantly keep the topic of equality-inequality a contemporary problem discussed in publications.

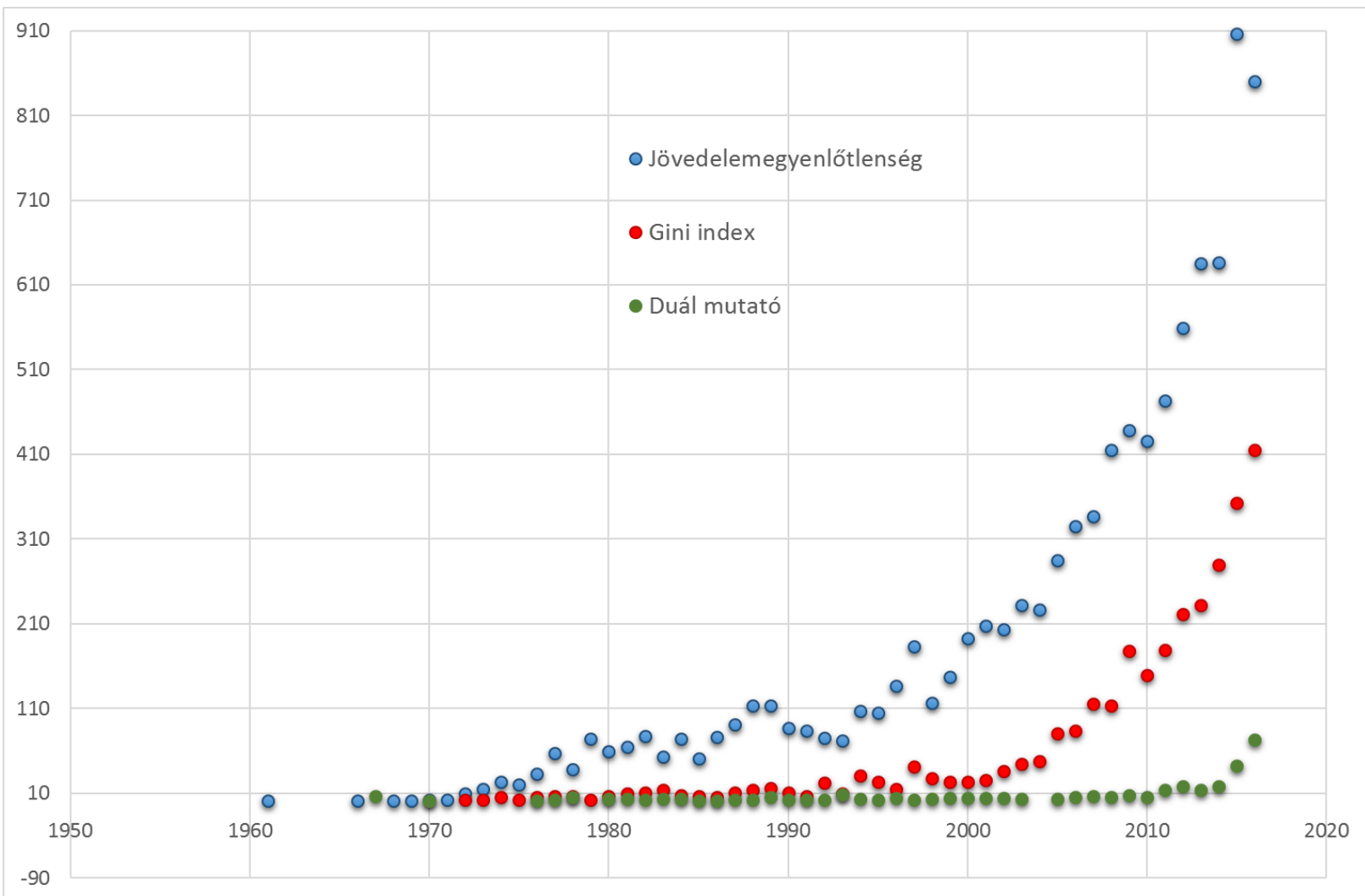

Figure 4. Frequency of appearance of income inequality, Gini index and dual index in Science Direct's database Source: Own compilation based on Science Direct`s database 
Introduced in 1914 by the Italian economist Corrado Gini (1884-1965), the Gini index`s popularity started its growth trajectory in the seventies. This economic index measures the inequalities in statistical distributions but is also able to summarize the income differences in a single number (Farris, 2010). Even though literature considers this as one of the most discussed indices, despite its disadvantages it has continuously gained popularity in the scientific research of the past 15 years.

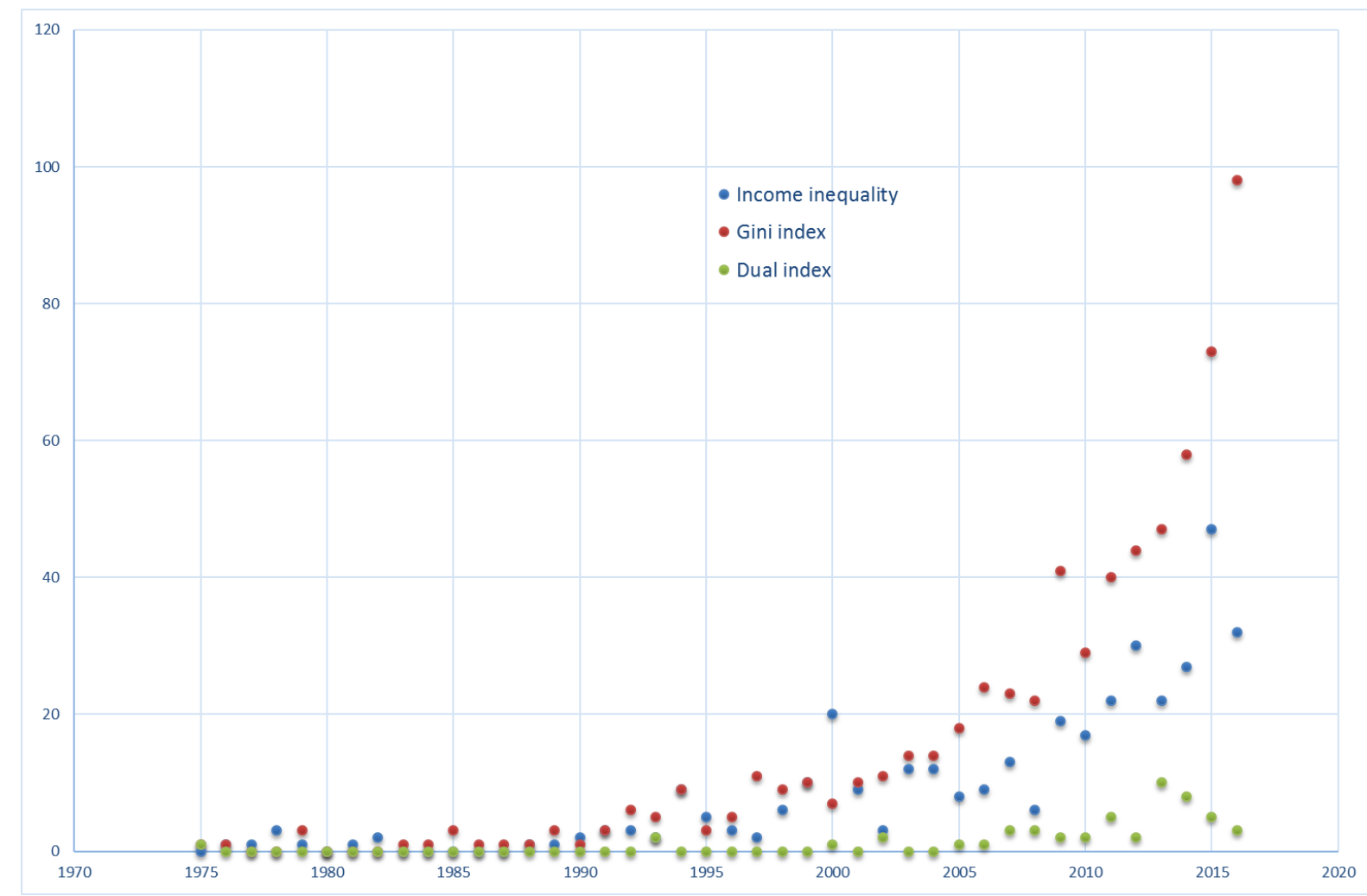

Figure 5. Frequency of appearance of income inequality, Gini index and dual index in Web of Science`s database

Source: Own compilation based on Web of Science`s database

Recent years have also given momentum to the Éltetö-Frigyes index (Dual index), defined by renowned Hungarians, which shows the scissor between the income levels of the averagely wealthy (above average) and the averagely poor (below average) (Nagy, 2009).

Poverty is almost as old as civilization itself. With the appearance of private property, people started to fight for the possession of certain goods, and naturally, there are some who are defeated in this fight. "In the middle ages, most of the people were right on the edge of being able to sustain themselves, but some indications can be found that certain cultures have taken steps to help the poor. With the appearance of renaissance and reformation, the way of thinking has been transformed and poverty has become socially unacceptable" (Darók, 2004). When it comes to the problems of the poor, those living on the periphery of society, it is unavoidable for the social scientists to take action. Statements concerning the quality and measure of social inequalities and the related migration processes form one of the outstanding dimensions of research, exemplified by this study. Investigating the wording of scientific articles in the past 200 years, interesting trendlines can be realized (Figure 6). Scientists of a multitude of disciplines also work on the processes mentioned before. 


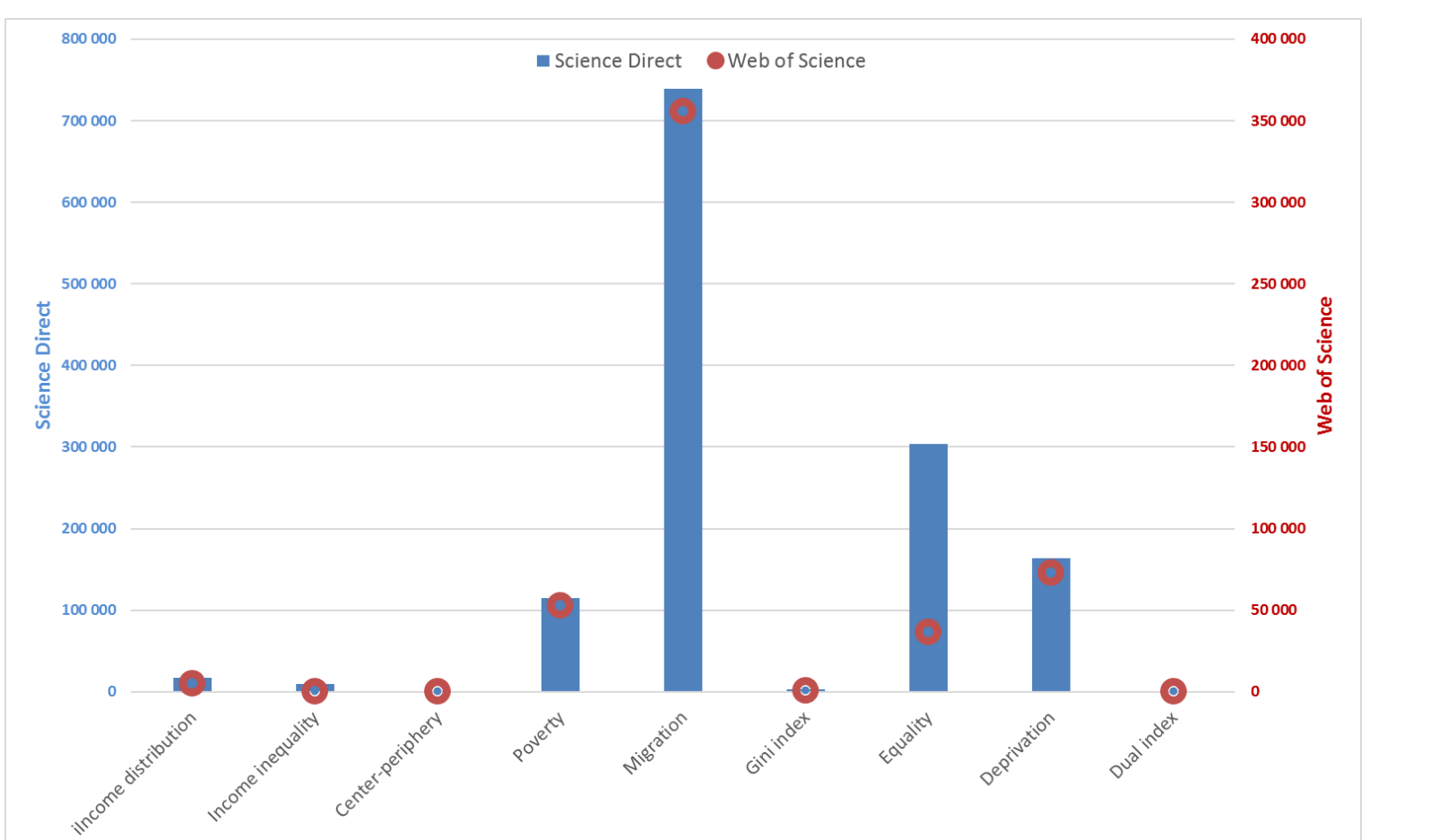

Figure 6. Frequency of keyword appearance in the databases Science Direct and Web of Science

Source: Own compilation based on Science Direct`s and Web of Science`s database

The following diagrams display the frequency of appearance of the words poverty, deprivation and migration. Examining the whole timeline of available data, it is notable (Figure 7 and Figure 8) that from the middle of last century onwards, researches placing special emphasis on the topic have grown exponentially (so much so, that the data of the previous two aforementioned diagrams are almost negligible). Background to this process is that after World War II, the development of the global economy accelerated immensely. However, the acceleration of the global economic development resulted in the accumulation of major socio-economic stresses and inequalities (Tóth, 2014). Such stresses are shown by some people in certain locations not having access to even elemental necessities, living the lives in distressingly poor circumstances.

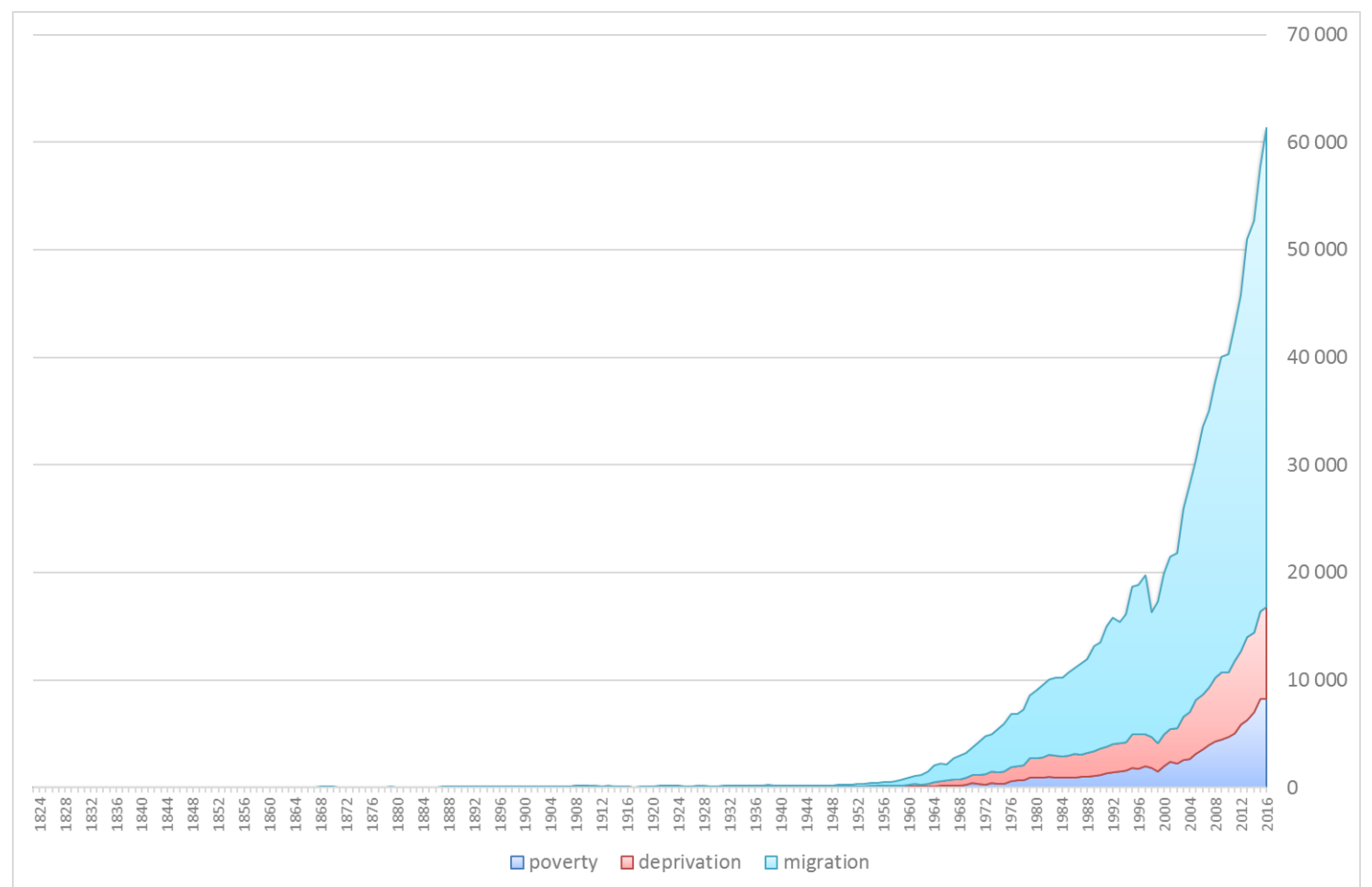

Figure 7. Frequency of appearance of poverty, deprivation and migration in Science Direct's database (1823-2016) Source: Own compilation based on Science Direct`s database 
The appearance of poverty, deprivation and migration in publications has gained huge momentum from the 1960s onwards. No wonder, since this marked the publishing of the Roman Club`s first report titled "The Limits to Growth". The work of four young researchers from 1972, the Meadows-report shows the nature of exponential growth and calls attention to its limits. A finite world cannot accommodate infinite growth, and there needs to be synergy between ecological and economic stability. The famous RIO-report`s renowned researchers also evaluate - in this era - the aforementioned problems, and formulated measures targeting a more humane and fairer international community. In the 1970s, various other world models stipulated the expected growth of the global economy, often times pointing out the boundaries and hidden dangers of expansion. The relatively quick and also unequal development of countries, the oil crisis in 1973-1974 and the fundamental and long-lasting realignment of global market prices, the already existing huge difference in the economies of developing countries increased further. For developing countries, the 1970s have not delivered expected results in this regard.

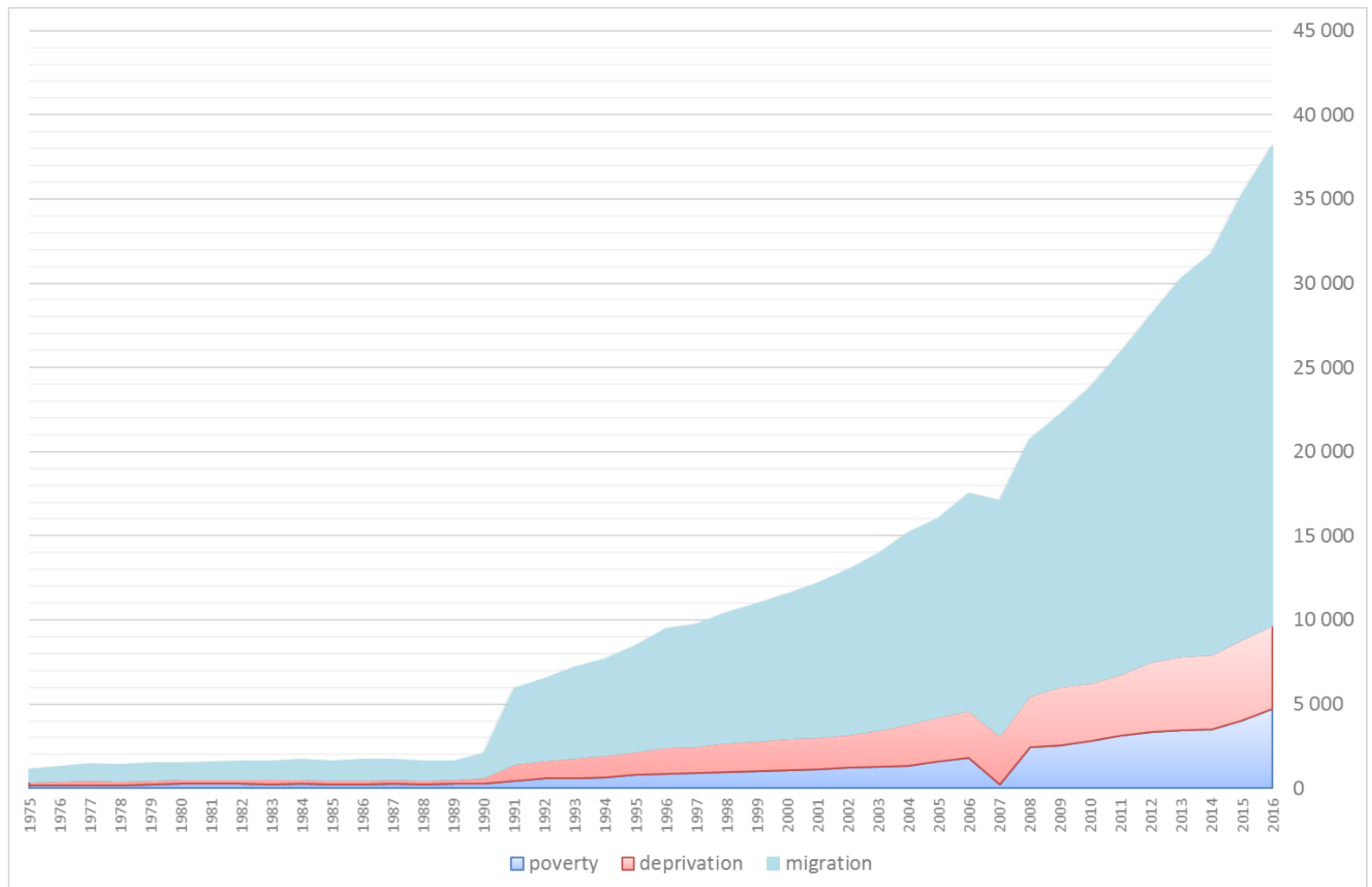

Figure 8. Frequency of appearance of poverty, deprivation and migration in Web of Science`s database between 1975-2016

Source: Own compilation based on Web of Science`s database

With distinctive importance, it can be proved from an economic point of view also, that the income differences result in significant migration processes. Worsening standards of living, poverty of an expanded number of people generate migration in search of improved quality life. The actuality of the topic in 2016 is still relevant.

Table 2 summarizes the title and country of publishers of journals in which the test keywords were most commonly featured in Science Direct's database.

Table 2. Title and country of publishers of TOP 3 journals or books in which the test keywords were most commonly featured in Science Direct's database

\begin{tabular}{|c|l|c|}
\hline Keyword & \multicolumn{1}{|c|}{ Title of TOP $\mathbf{3}$ journals or books } & Country of Publisher \\
\hline $\begin{array}{c}\text { income } \\
\text { distribution }\end{array}$ & $\begin{array}{l}\text { World Development } \\
\text { Journal of Public Economics } \\
\text { Journal of Development Economics }\end{array}$ & $\begin{array}{c}\text { Netherlands } \\
\text { Notherlands }\end{array}$ \\
\hline $\begin{array}{l}\text { World Development } \\
\text { Social Science \& Medicine } \\
\text { Journal of Development Economics }\end{array}$ & $\begin{array}{l}\text { UK } \\
\text { UKequality }\end{array}$ \\
\hline
\end{tabular}


Table 2 (cont.). Title and country of publishers of TOP 3 journals or books in which the test keywords were most commonly featured in Science Direct's database

\begin{tabular}{|c|c|c|}
\hline Keyword & Title of TOP 3 journals or books & Country of Publisher \\
\hline center-periphery & $\begin{array}{l}\text { International Encyclopedia of the Social \& Behavioral Sciences } \\
\text { World Development } \\
\text { Political Geography }\end{array}$ & $\begin{array}{l}\text { USA } \\
\text { UK } \\
\text { UK }\end{array}$ \\
\hline poverty & $\begin{array}{l}\text { The Lancet } \\
\text { Social Science \& Medicine } \\
\text { World Development }\end{array}$ & $\begin{array}{l}\text { UK } \\
\text { UK } \\
\text { UK }\end{array}$ \\
\hline subsistence level & $\begin{array}{l}\text { World Development } \\
\text { Journal of Development Economics } \\
\text { Ecological Economics }\end{array}$ & $\begin{array}{l}\text { UK } \\
\text { Netherlands } \\
\text { Netherlands }\end{array}$ \\
\hline migration & $\begin{array}{l}\text { Journal of Chromatography A } \\
\text { Gastroenterology } \\
\text { Biochemical and Biophysical Research Communications }\end{array}$ & $\begin{array}{l}\text { Netherlands } \\
\text { UK } \\
\text { USA }\end{array}$ \\
\hline Gini index & $\begin{array}{l}\text { Expert Systems with Applications } \\
\text { World Development } \\
\text { Social Science \& Medicine }\end{array}$ & $\begin{array}{l}\text { UK } \\
\text { UK } \\
\text { UK }\end{array}$ \\
\hline equality & $\begin{array}{l}\text { Journal of Mathematical Analysis and Applications } \\
\text { Linear Algebra and its Applications } \\
\text { IFAC Proceedings Volumes }\end{array}$ & $\begin{array}{l}\text { USA } \\
\text { Netherlands } \\
\text { Austria }\end{array}$ \\
\hline equal & $\begin{array}{l}\text { The Lancet } \\
\text { IFAC Proceedings Volumes } \\
\text { Physics Letters B }\end{array}$ & $\begin{array}{l}\text { UK } \\
\text { Austria } \\
\text { Netherlands }\end{array}$ \\
\hline deprivation & $\begin{array}{l}\text { Physiology \& Behavior } \\
\text { Brain Research } \\
\text { The Lancet }\end{array}$ & $\begin{array}{l}\text { Netherlands } \\
\text { Netherlands } \\
\text { UK }\end{array}$ \\
\hline dual index & $\begin{array}{l}\text { Molecular Phylogenetics and Evolution } \\
\text { Cell } \\
\text { Science of The Total Environment }\end{array}$ & $\begin{array}{l}\text { USA } \\
\text { USA } \\
\text { Netherlands }\end{array}$ \\
\hline
\end{tabular}

Source: Own compilation based on Science Direct database

Mostly in these journals prefer topics related to keywords. The publishers of TOP 3 journals or books are usually in the UK, in the USA and in the Netherlands.

\section{Conclusions}

The 21st century is the era of societies burdened with inequalities. Multidirectional stratification is present within social groups, which is also expressed in differences of income. Scientific papers provide an overview in various sections about the problems of societal stratification, and the equality-inequality, balance-imbalance questions take almost daily roles in various studies. Extreme poverty (Bradshaw et al., 2010) is an often used expression today. It is used in cases where a person lives under the minimum standard of living for an extended amount of time and has little chance of breaking out of this situation. Living in extreme poverty can have multiple different causes: social and economic deficits present themselves and cause severe disturbances in the standard of living. This state stereotypes the suffering very quickly and causes them to be excluded from society. Societal exclusion is therefore mostly the result of circumstances related to poverty, and in many cases causes migration.

Our hypothesis seems to be valid in light of the emergence of income inequality as a major topic next to income distribution - as the governmental action for social equalization. The two are naturally not separable, but this is still important information, since the bigger the income inequality is in an economy, the bigger the steps governments need to take in order to eliminate the problem. Actions against poverty and social exclusion aim to reduce the numbers of those living in extreme poverty, outside of society. As it has been referred to, studies concerning income inequalities have brought along with them various forms of measuring income differences. Despite its advantages, the Gini-index, developed by Corrado Gini deserves special attention, since it has been popularly used to quantify income differences and has become prevalent in the past 15 years. Most recently the Hungarian-developed Éltetö-Frigyes index has also earned recognition in scientific circles.

Speaking of problems of the poor and those on the edges of society, social scientist must take part in the conversation. Statements about the quality and measure of social inequalities, as well as the related migration processes form a significant dimension of research. Every person has the right to live his or her live in equal dignity, which must be the basis for a fairer economic and social system (Deli, 2015). 
Our article summarized the most important findings from our perspective while introducing the major changes in scientific research since the 1970s. We believe that the studies allow for greater advances in solving global problems for a new and fairer global economic order, as they focus on this important topic in ever more investigations. The publishers of TOP 3 journals or books are usually in the UK, in the USA and in the Netherlands. Mostly in these journals prefer topics related to keywords.

\section{References}

1. Berelson, B. (1952). Content Analysis. Free Press, New York.

2. Bokor, Á. (1987). Szegénység a mai Magyarországon [Poverty in Today's Hungary]. Budapest, Magvető Kiadó.

3. Bradshaw, J., Mayhew, E. (2010). The Measurement of Extreme Poverty in the European Union. Resource document. European Commission, Directorate-General for Employment, Social Affairs and Inclusion. Available at: https://ec.europa.eu/social/BlobServlet?docId=6462\&langId=en. Accessed 25 October 2018.

4. Darók, I. (2004). Szegények, munkanélküliek, hajléktalanok [Poors, unemployed, homeless]. Social Studies Text Collection. Alapítvány a Társadalomelméleti Kollégiumért, Budapest, 33-56.

5. Deli, G. (2015). Human Dignity, Historical Narratives and Law. An Outline of Today's Prospects of Natural Law. Iustum Aequum Salutare, 11(1), 41-58.

6. Farris, F.A. (2010). The Gini Index and Measures of Inequality. The American Mathematical Monthly, DOI: $10.4169 / 000298910 X 523344$.

7. Gyuris, F. (2014). Az egyenlőtlen földrajzi fejlődés koncepciója [The Concept of Uneven Geographic Development]. Földrajzi Közlemények, 138(4), 293-305.

8. Harangozó, G. (2015). Gazdasági és pénzügyi nevelés [Economic and Financial Education]. Pedagógiai tanulmányok, (276), PPKE BTK, Budapest, 205-229.

9. Heyne, P. (1991). A gazdasági gondolkodás alapjai [The Basics of Economic Thinking]. Budapest, Tankönyvkiadó.

10.Hunyady, L. (2006). Beszélgetés Éltető Ödönnel [Conversation with Ödön Éltetö]. Statisztikai Szemle, 84(10-11), 1018-1022.

11.Huygens, C. (1654). Illustrium Quorundam Problematum Constructiones. De Circuli Magnitudine Inventa, 45-72.

12.Kovács, I. (2010). A hazai jövedelemeloszlás és jövedelemegyenlötlenség mérése és elemzése személyi jövedelem-bevallási adatok alapján [Measurement and Analysis of Domestic Income Distribution and Income Inequality Based on Personal Income Tax Return Data]. MTA Közgazdaságtudományi Intézet Mühelytanulmányok MT-DP-2010/9.

13.Nagy, H. (2009). Regional Policy. Szent István University, University Note, Gödöllő.

14.Nemes Nagy, J. (2009). Terek, helyek, régiók [Spaces, Places and Regions]. Budapest, Akadémiai Kiadó, 206-214.

15.Meadows, D., \& Randers, J., \& Meadows, D. (2005). A növekedés határai. Kossuth Kiadó [The Limits of Growth - Thirty years later]. Budapest, Kossuth Kiadó.

16.Organisation for Economic Co-operation and Development (2008). Growing Unequal? Income Distribution and Poverty in OECD Countries. DOI: https://dx.doi.org/10.1787/9789264044197-en.

17.Pataki, Gy., \& Radácsi, L. (2000). Alternatív kapitalisták [Alternative Capitalists]. Szentendre, Új Paradigma Kiadó.

18.Piketty, T. (2015). A töke a 21. században [The Capital in the 21st Century]. Budapest, Kossuth Kiadó.

19.Sheshinski, E. (1972). Relation between a Social Welfare Function and the Gini Index of Income Inequality. Journal of Economic Theory, 4(1), 98-100.

20.Szigeti, C. (2014). Tudományos divattrendek a fenntarthatóságban [Scientific Fashion Trends in Sustainability]. LVI. Georgikon Napok Konferencia, Keszthely. 2014.10.02-03., 414-422.

21.Tinbergen, J. (1979). A RIO-jelentés. A nemzetközi gazdasági rend átalakítása [The Rio Report. Transforming the International Economic Order]. Budapest, Közgazdasági és Jogi Könyvkiadó.

22.Tóth, G. (2016). Gazdasággép [Economicmachine]. Budapest, L'harmattan.

23.Tóth, J. (2014). General Social Geography I-II. Budapest, Dialóg Campus Kiadó.

24.Wilkinson, R.G., \& Pickett, K.E. (2006). Income Inequality and Population Health: a Review and Explanation of the Evidence. Social Science \& Medicine, 62(7), 1768-1784. DOI: 10.1016/j.socscimed.2005.08.036.

25.Wood, D.A. (1970). The Feasibility of a Discrepant Approach in Assessing Job Attitudes. Organizational Behavior and Human Performance, 5(6), 555-575. 